\title{
Real Data Type
}

National Cancer Institute

\section{Source}

National Cancer Institute. Real Data Type. NCI Thesaurus. Code C95826.

A data type comprised of fractional numbers. 